Agro-Science Journal of Tropical Agriculture, Food, Environment and Extension Volume 19 Number 3 (July 2020) pp. $25-31$

ISSN 1119-7455

\title{
PRODUCTION AND MANAGEMENT OF GOAT REARING IN RURAL AREAS OF EZINIHITTE MBAISE, IMO STATE, NIGERIA
}

\author{
*Nwachukwu C.U. and Berekwu N. \\ Department of Agricultural Science, School of Agriculture \& Vocational Studies, \\ Alvan Ikoku Federal College of Education, Owerri 460281, Imo State, Nigeria \\ *Corresponding author's email: chinwe.nwachukwu@alvanikoku.edu.ng
}

\begin{abstract}
This study assessed production and management practices of indigenous goat rearing in the rural communities of Ezinihitte Mbaise, Imo State. Data were collected from 150 goat farmers in Ezinihitte Mbaise with the use of structured questionnaire in 2014 for data collection. The questionnaire was on the socio-economic characteristics of goat farmers, factors influencing and constraints on production and management of goat rearing. The mean age of goat farmers was 51 years and 86 percent were males. The farmers' level of education was primary education (60\%), secondary education (22\%), and tertiary education (18\%). Majority (52\%) of the household size were 4-7 persons with mean household size of 4 persons. Farming experience was mostly short (62\%) having only 1-5 years. The result showed that coefficient of age, farm size, educational level, household size and years of experiences were the factors that influenced goat production and management in the study area. Farm size, family labour and capital were shown to be crucially important for goat production and management. The farmers had an over-utilized resource in goat production and a decrease in resources increased proportional output. Most of the farmers practisedextensivesystem of production as the most commonly used system by goat farmers. Poor veterinary services, inadequate skilled labour, poor housing facilities, poor road network, market problems, high disease and pest incidence, high cost of animal drugs, and feeds are the constraints faced by goat farmers. The study recommends strong efforts to educate and retain the experienced goat farmers to ensure increase output and productivity.
\end{abstract}

Key words: goat rearing, production, management, constraints

\section{INTRODUCTION}

Africa accounts for over $30 \%$ of the total small ruminant population in the world with an estimation of 205 million sheep and 174 million goats representing approximately $17 \%$ and $31 \%$ of livestock production. However, from 1980 till 2005, ruminant production in Africa has increased to $75 \%$ goat, $44 \%$ cattle, and $43 \%$ sheep according to FAOSTAT (2008), with the majority of goats from sub-Saharan Africa (Wint and Robinson, 2007; FAOSTAT, 2008; Simela and Merkel, 2008). Africa has about 180 indigenous goat breeds, distributed across all agro-ecological zones in the continent (Lebbie, 2004). Nigeria specifically has about 15 million cattle, and 49 million sheep/goats representing about $63.7 \%$ of the total grazing livestock (FAO, 2005; Livestock Report, 2006). Interestingly, indigenous goats are highly adaptive to different production systems ranging from pastoral to agro-pastoral system with traits such as long walking ranges, ability to selectively graze and feed on poor quality forage, efficient utilisation of marginal environments, and low capital investment. Generally, goats are endowed with special attributes such as heat tolerance, disease resistance, short generation interval, and high reproduction rate (Oguoma, 2003; Lebbie, 2004).
As a multipurpose animal, goats provide meat, milk, hides, skins and manure. Goat production plays a significant role in the improvement of human nutrition (Adam et al., 2010), and contribute about $17 \%$ of the total meat and $12 \%$ of milk production in Africa (Lebbie, 2004). Goat milk is rarely used in large quantity for human consumption, however, there is a growing awareness of the importance of goat milk to man. Current goat production yields $60 \%$ of its value as milk, $35 \%$ of meat, and $5 \%$ as skin. Goat has higher feed conversion efficiency to meat and milk than cattle, sheep and buffaloes and globally, goat milk is more widely produced and accepted than sheep milk. Smallholders also use goat dung to improve general soil fertility and expand cultivated farmlands (Karbo et al., 1999). Small ruminants have a significant cultural role in rural areas as goat plays a significant role in marriage and burial rights in most local communities in Africa especially in Nigeria(Lebbie, 2004; Ajala et al., 2008).Goat production constitutes a very important part of the rural economy with more than $95 \%$ of the rural households keeping goats and ranks next to cattle in income generation and economic sustenance (Duku et al., 2011). Goats are owned by rural farmers within all age range and genders. Small ruminant production systems have been studied in 
Southeast Nigeria at extensive and semi-extensive systems as fodder is supplemented to goat production with household kitchen waste. Indigenous goats are primarily reared under traditional free-range system, characterized by high mortality, high morbidity and low productivity. In tropical environments, small ruminant(goat) production systems are characterised by low performance compared to temperate breeds as animals are either allowed to roam or graze for hours daily or permanently confined (Ajala et al., 2008).

Attempts by farmers, cooperatives and agricultural groups to improved and encourage commercial goat production are complicated as they are still poor production and management practices (Oyeranti and Olayiwola, 2005; Poole et al., 2013). This may be as a result of insufficient veterinary services, high disease risk, cost of feed, poor infrastructure and unavailable credit facilities. The low educational level of the farmers' knowledge, skills, experience, and poor awareness of new techniques and technologies often result in poor goat production (Ali et al., 2002). Consequently, goat farmers face high production costs with limited revenue, poor market channels, and thus need a clear supported training to improve output and productivity (Godfray et al., 2010; Thornton, 2010). The low levels of farm size, technical and economic inefficiency coupled with low technological uptake have held back productivity and development of goat production system in Nigeria.

The need to efficiently increase agricultural outputs especially in animal husbandry has been widely recognized by scientists, researchers and policy makers. Therefore, analysing the goat production and management system to develop more efficient use of existing technologies and increase productivity is pivotal (Ajibefun and Daramola, 2003). With the production and management of goat production system, this study specifically assessed indigenous goat production system and management practices in Ezinihitte Mbaise, Imo State with the specific objectives of analysing the factors influencing indigenous goat production and management practices, resources used in indigenous goat production and management, and identify constraints mitigating against indigenous goat production, and management system among goat farmers in the study area.

\section{MATERIALS AND METHODS}

\section{Study Area}

The study was conducted in Ezinihitte Mbaise Local Government Area (LGA) between latitude $5^{\circ} 28^{\prime} \mathrm{N}$ and longitude $7^{\circ} 02^{\prime} \mathrm{E}$. The study area is humid rainforest rich in fertile arable agricultural land for farming. The agro-ecological conditions of the area are: 1,500 to $2,200 \mathrm{~mm}$ mean annual rainfall, $20^{\circ} \mathrm{C}$ ambient temperature, $75-90 \%$ relative humidity at $200 \mathrm{~m}$ above sea level. The research area has an average of 7 months rainy season from April to October and dry season of October to March with the hottest months in December to March. Ezinihitte Mbaise LGA is bounded in the South by Aboh Mbaise LGA, West by Ahiazu Mbaise LGA and North by Obowo LGA. The study area has predominantly (99\%) Igbo speaking people whose main occupation are education, farming, skilled work and trading (Okali et al., 2001). The main foods crops produced in the research area are Yam (Dioscorea), cocoyam (Colocasia esculenta), Rice (Oryza sativa), cassava (Manihot esculenta), Maize (Zea mays), vegetables (Telfairia ocidentalis), Banana (Musa sapientum), plantain (Musa paradisdaca), paw paw (Carica Papaya), pineapple (Ananas comosus), tree crops of oil palm (Elaeis guineensis), rubber (Hevea brasiliensis), breadfruit (Treculia africana), cashew (Anacardium occidentale), orange (Citrus sinensis), mango (Magnifera indica), and coconut (Coconut nucifera).

\section{Sampling and Data Collection}

The study sampled 15 autonomous communities in the three sub-zones of Ezinihitte Mbaise LGA; EziEast (Onisha, Eziudo, Obizi, Udo), Ezi-West (Ife, Owutu, Oboama, Umunama, Chokoneze, Akpodim), and Ezi-Centre (Amumara, OkpofeIhitte, Itu, Eziagbogu). The selected autonomous communities were chosen based on the concentration of goat production, human population, accessibility of transport, diverse occupations, farmers' income levels, number of goat farmers in the study area.

Multi-stage with random sampling procedures was adopted for the study. Ten goat farmers were randomly selected and used for the study in each autonomous community. Structured questionnaires with oral interviews were used to collect the primary data from 150 goat farmers for the study. Reliable and validated interview guides were used alongside the questionnaire to obtain information on the goat production and management practices in the area.

The data obtained were analysed and summarised using descriptive statistics, frequency distribution, and multiple regression models' analysis. The collected metadata covered the socioeconomic characteristics of the goat farmers, factors affecting goat production and management practices, resources used in indigenous goat production, and constraints affecting goat production and management practice in Ezinihitte Mbaise LGA of Imo State.

\section{Data Analysis}

Descriptive statistics of frequency and percentages were used to describe the socioeconomic characteristics of the goat farmers and method of production system in the study area. The Ordinary Least Square regression model was used to determine the effect of the socioeconomic factors on the quantity of output produced in a production year. 
Linear regression analysis was used to establish the relationship between the variables to know the factor that affects output per production year. The four functional regression models used were simple linear, semi-logarithmic, double-logarithmic and exponential. It shows how the dependent variable varies based on the input level of the independent variables. The criteria used in selecting the functional equation that gave the best fit for the regression analysis included: (i) highest $\mathrm{R}^{2}$, (ii) highest number of significant variables, (iii) highest $\mathrm{F}$ value and (iv) conformity to the apriori expectations of the regression coefficients. The linear regression model was selected for estimating the influence of socio-economic factors on output. Data were analysed using the Statistical Package for Social Sciences (SPSS) Version 16.

The model was expressed as:

$$
\mathrm{Y}=f\left(\mathrm{X}_{1}, \mathrm{X}_{2}, \mathrm{X}_{3}, \mathrm{X}_{4}, \mathrm{X}_{5}, \mathrm{X}_{6}, \mu\right) \text {, }
$$

where $Y$ is dependent variable, $\mathrm{X}_{1}, \mathrm{X}_{2}, \ldots . \mathrm{X}_{\mathrm{n}}$ are independent variables, $f$ is output, $\mu$ is error term. The independent variables included $X_{1}$, age of the goat farmers (which was expected to have a positive effect on the output); $\mathrm{X}_{2}$, farm size or stock density (expected to have a negative effect on the output); $\mathrm{X}_{3}$, education level (expected to have a positive effect on the output); $\mathrm{X}_{4}$, household size (expected to have a positive effect on the output); $\mathrm{X}_{5}$, years of experience (expected to have a positive effect on the output); $\mathrm{X}_{6}$, gender (expected to have a positive effect on the output); and $\mu$, error term (assumed to be normally distributed with zero mean and constant variance).

Cobb-Douglas functional form was also used for the estimation of resource use and allocation efficiency parameters. The Marginal Value Products (MVPs) of the production inputs using coefficients of the inputs from the estimated Cobb-Douglas output. The MVP was computed for each input as the product of its regression coefficient, the geometric mean valve of farm revenue and the farm input. A given resource was optimally allocated when there is no divergence between its MVP and its acquisition cost (i.e., marginal factor cost MFC)). The decision rule was that the farmer maximizes its profit with respect to an input if the ratio of its MVP to its MFC is unity. A ratio less than unity shows overutilization of that resource and profit would be increased by decreasing the quantity used on that input. Resource underutilization is indicated by a ratio greater than one and profit would be increased by an increase in the rate of its use.

\section{RESULTS}

The socio-economic characteristics of the goat farmers are presented in Table 1. The result showed that $86.00 \%$ of the goat farmers were males while $14.00 \%$ were females. About $46.67 \%, 43.33 \%$, and $10.00 \%$ of the goat farmers were within the age bracket of 60-79 years, $40-59$ years and 20-39 years respectively. With a mean age of the goat farmers was 51 years. The result showed that $60 \%$ of the goat farmers attended primary school, $22 \%$ had secondary education and $18 \%$ had tertiary education.

The study indicated that $52 \%$ of goat farmers had a household size of 4-7 people, $46 \%$ had $0-3$ persons and $2 \%$ had greater than 8 persons, where the mean household size was 4 persons. The mean farming experience of the goat farmers was 5.41 years where majority (62\%) had $1-5$ years of farming experiences, about $25.33 \%$ had $6-10$ years of experience, $10 \%$ had 11-15 years of experience, $2 \%$ had above 21 years of experience, and $0.67 \%$ had 16-20 years of experience.

The farm size was measured by the number of goats in the herd, referred here to as stock density. The farm size showed that $20 \%$ of the goat farmers had $<6$ or $>21$ goats, $19.33 \%$ had $11-15$ goats, $16.67 \%$ had $16-20$ goats, $13.33 \%$ had $6-10$ goats and $10.67 \%$ had 26-30 goats in stock.

The monthly income distribution of farmers showed that $52 \%$ of the goat farmer received between $\$ 20,001$ and $\$ 30,000$ as their income, $20 \%$ had between $\$ 10,000$ and $\$ 20,000,11.33 \%$ had between $\$ 40,001$ and $\$ 50,000$, while $10 \%$ had between $\$ 30,001$ and $\$ 40,000$. The average monthly income of goat farmers was $\$ 21,431$ per month.

Table 1: Socio-economic characteristics of the goat farmers

\begin{tabular}{|c|c|c|}
\hline Variable & Frequency & Percentage \\
\hline \multirow{2}{*}{$\begin{array}{ll}\text { Gender } & \text { Female } \\
\text { Male }\end{array}$} & 21 & 14.00 \\
\hline & 129 & 86.00 \\
\hline \multicolumn{3}{|l|}{ Age } \\
\hline $20-39$ & 15 & 10.00 \\
\hline $40-59$ & 65 & 43.33 \\
\hline $60-79$ & 70 & 46.67 \\
\hline Mean age & 51.45 & \\
\hline \multicolumn{3}{|l|}{ Educational level } \\
\hline Primary education & 90 & 60.00 \\
\hline Secondary education & 33 & 22.00 \\
\hline Tertiary education & 27 & 18.00 \\
\hline \multicolumn{3}{|l|}{ Household size } \\
\hline $0-3$ & 69 & 46.00 \\
\hline $4-7$ & 78 & 52.00 \\
\hline Above 8 & 3 & 2.00 \\
\hline Mean household size & 3.68 & \\
\hline \multicolumn{3}{|l|}{ Farming Experience } \\
\hline $1-5$ & 93 & 62.00 \\
\hline $6-10$ & 38 & 25.33 \\
\hline $11-15$ & 15 & 10.00 \\
\hline $16-20$ & 1 & 0.67 \\
\hline $21-25$ & 3 & 2.00 \\
\hline Mean farming experience & 5.41 & \\
\hline \multicolumn{3}{|l|}{ Farm size } \\
\hline $1-5$ & 30 & 20.00 \\
\hline $6-10$ & 20 & 13.33 \\
\hline $11-15$ & 29 & 19.33 \\
\hline $16-20$ & 25 & 16.67 \\
\hline $21-25$ & 30 & 20.00 \\
\hline $26-30$ & 16 & 10.67 \\
\hline \multicolumn{3}{|l|}{ Income per month } \\
\hline$\approx 10,000-\$ 20,000$ & 30 & 20.00 \\
\hline$\approx 20,001-\$ 30,000$ & 78 & 52.00 \\
\hline$\$ 30,001-\$ 40,000$ & 15 & 10.00 \\
\hline$\$ 40,001-N 50,000$ & 17 & 11.33 \\
\hline Above $¥ 51,000$ & 10 & 6.67 \\
\hline Mean income & N21,431 & \\
\hline
\end{tabular}

Source:- Field data, 2014 
The occupational status of the goat farmers is presented in Figure 1. The result shows that $21.33 \%$ of the goat farmers were involved in teaching, $20 \%$ involved in both crop and livestock farming (mixed farming), $18 \%$ were traders, $16.67 \%$ were civil servants, and $4 \%$ were involved in fishing.

The socio-economic variables of the farmers were fitted into the four functional forms of the multiple regression models to ascertain the various factors influencing goat production in the study area as described in Table 2. The choice of the equation was based on econometric criteria:- the number, levels and signs of the significant variables, accordance with a prior expectation and a high Regression $\left(R^{2}\right)$ value. Result in Table 2 showed that the lead equation was the linear function, followed by double-log and exponential function. The $R^{2}$ value was $0.903,0.868$, and 0.751 indicating that $90.30 \%, 86.80 \%$, and $75.10 \%$ variation in the output of the goat farmers were well explained by the socioeconomic variables- age, farm size, level of education, household size, and years of farming experience were the significant factors affecting goat production in the study area.

Table 3 shows the Cobb Douglas production function of the resources used in goat production. Most of the inputs were positively affected by the goat production output excluding the cost of input, cost of feed and capital that had a negative effect on the production output. The coefficients of farm size, family labour and capital inputs were positive and significant at $1 \%$ level of probability.

Parameters of the production function are expressed in Table 4. The result showed the analysis of the resources used in goat production and allocation efficiency of the resources for maximum production and output. The allocative efficiency value for production input is the ratio of MVP to MFC of the various inputs. The MVP of an input in this context is the product of its estimated production function parameter, marginal physical product and price of output. Furthermore, result indicates the allocative efficiency values of farm size (0.84), family labour (0.01) and capital (0.725), respectively.

Figure 2 shows the goat production systems practised by the goat farmers in the study area. The result revealed that $76.67 \%$ of goat farmers practised extensive system of goat production, $16.67 \%$ practiced semi-intensive system and $6.67 \%$ practiced intensive system in the study area.

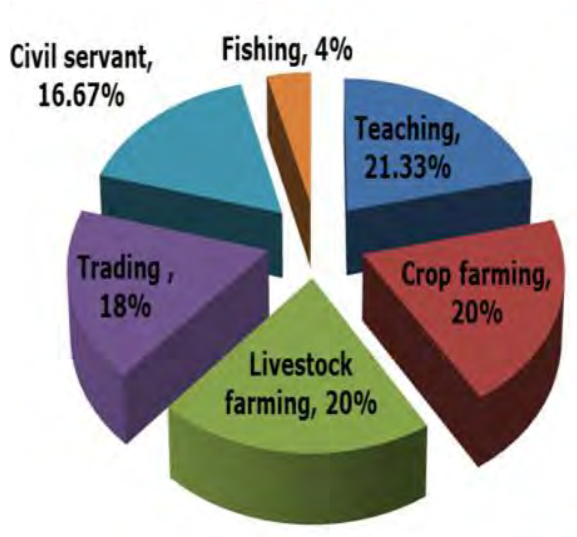

- Teaching

Crop farming

- Livestock farming

Trading

- Civil servant

I Fishing

Figure 1: Distribution of goat farmers by their occupation

Table 3: Estimated output of Cobb-Douglas production functions

\begin{tabular}{llll} 
production functions & Regression \\
Variables & t-statistics & $\begin{array}{l}\text { Signifi- } \\
\text { cance }\end{array}$ \\
\hline Farm size & 0.559 & $8.208^{* * *}$ & 0.000 \\
Cost of input & -0.037 & -0.630 & 0.530 \\
Family labour & 0.295 & $4.086 * * *$ & 0.000 \\
Hired labour & 0.097 & 1.645 & 0.102 \\
Cost of medication & 0.084 & 1.624 & 0.107 \\
Cost of feed & -0.040 & -0.792 & 0.429 \\
Capital & -0.120 & $-2.196 * *$ & 0.030 \\
\hline Source:- Field data, 2014. Significant at $* * * 1 \%$ and $* * 5 \%$
\end{tabular}

Table 4: Estimated marginal value products (MVP), marginal factor costs (MFC) and allocative efficiency values

\begin{tabular}{lcccc}
\hline Input & MVP & MFC & $\begin{array}{c}\text { Allocative efficiency } \\
\text { values (MVP/MFC) }\end{array}$ & $\begin{array}{c}\text { Decision } \\
\text { rule }\end{array}$ \\
\hline $\begin{array}{l}\text { Farm } \\
\text { size }\end{array}$ & 1.632 & 1,923 & 0.84 & Overutilized \\
$\begin{array}{l}\text { Family } \\
\text { labour }\end{array}$ & 14.54 & 1,428 & 0.01 & Overutilized \\
Capital & 870 & 1,200 & 0.725 & Overutilized \\
\hline
\end{tabular}

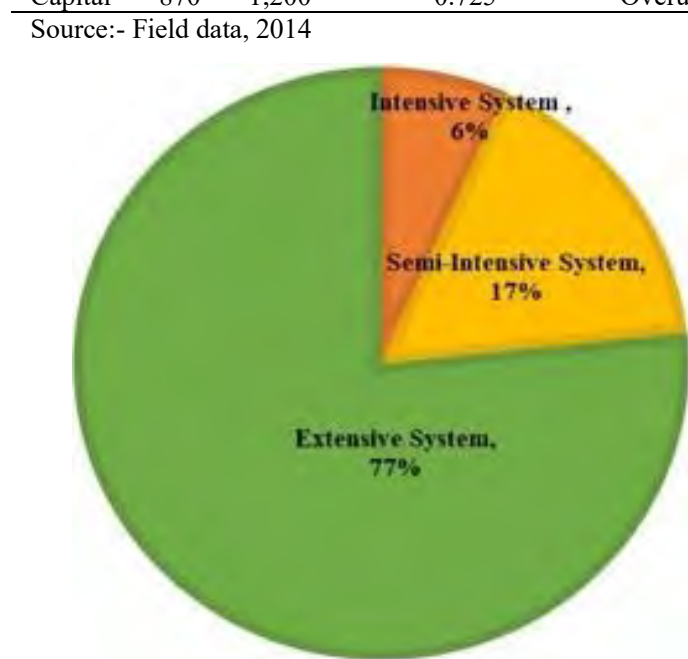

Figure 2: The goat production systems by the goat farmers

Table 2: Regression analysis on socio-economic characteristics of the farmers

\begin{tabular}{|c|c|c|c|c|}
\hline Variables & Linear & Exponential & Some-log & Double-log \\
\hline Age & $0.525(12.122)^{* * *}$ & $0.582(8.382)^{* * *}$ & $0.558(7.792)^{* * *}$ & $0.690(14.197)^{* * *}$ \\
\hline Farm size & $-0.143(-4.650)^{* * *}$ & $-0.129(-2.625)^{* * *}$ & $-0.057(-1.066)$ & $-0.101(-2.812)^{* * *}$ \\
\hline Educational level & $0.488(10.409)^{* * *}$ & $0.277(3.683)^{* * *}$ & $0.321(4.364)^{* * *}$ & $0.258(5.159)^{* * *}$ \\
\hline Household size & $0.054(1.895)^{* * *}$ & $0.204(4.426)^{* * *}$ & $0.039(0.740)$ & $0.112(3.126)^{* * *}$ \\
\hline Years of experience & $0.056(1.943)^{* * *}$ & $0.015(0.327)$ & $0.056(1.118)$ & $0.020(0.577)$ \\
\hline Gender & $0.029(1.051)$ & $-0.016(-0.363)$ & $-0.037(-0.734)$ & $-0.041(0.229)$ \\
\hline $\mathrm{R}^{2}$ & 0.903 & 0.751 & 0.713 & 0.868 \\
\hline F-ratio & $222.423^{* * *}$ & $72.009^{* * *}$ & $59.150^{* * *}$ & $156.551^{* * *}$ \\
\hline Constant & $-0.277(0.045)^{* * *}$ & $-2.057(-19.339)^{* * * *}$ & $-4.372(9.229)^{* * *}$ & $-8.809(-18.793)^{* * *}$ \\
\hline
\end{tabular}

Source:- Field data, 2014. ${ }^{* * *}$ significant at $1 \%,{ }^{* *}$ significant at $5 \%$. 
Table 5: Constraints of goat production and management practice in the study area

\begin{tabular}{lll}
\hline Constraints & Frequency & Percentage (\%) \\
\hline Poor veterinary services & 115 & 76.67 \\
Inadequate skilled labour & 100 & 66.67 \\
Poor housing facilities & 81 & 54.00 \\
Poor road network & 73 & 48.67 \\
Market problems & 69 & 46.00 \\
High disease incidence & 65 & 43.33 \\
High cost of drugs & 50 & 33.33 \\
High cost of feed & 21 & 14.00 \\
\hline Source:- Field data, 2014 &
\end{tabular}

Source:- Field data, 2014

The constraints militating against goat farmers in the study was presented in Table 5. The result showed that poor veterinary services (76.67\%), inadequate skilled labour $(66.67 \%)$, poor housing $(54 \%)$, poor road network $(48.67 \%)$ and market problems (46\%) were the major constraints militating against indigenous goat farmers in the study area.

\section{DISCUSSION}

The study assessed production and management practices of indigenous goat rearing in rural areas of Ezinihitte Mbaise, Imo State. The socioeconomic characteristics of the goat farmers that influence goat production in the study area are presented in Table 1 with its regression analysis in Table 2.

The socioeconomic characteristics of the goat farmers revealed that majority of farmers that reared goats were males and not females. The more participation of men in goat farming showed that they were economically autonomous within the household. The result corroborates with the studies from Northern Ghana and Gambia that observed male farmers were the principal producers and owners of both sheep and goats (Jaitner et al., 2001; Adams and Ohene-Yankyera, 2014). In contrast, a study from Southern Benin showed that female farmers also manage goats (Dossa et al., 2008).

The study found that the goat farmers had a mean age of 51 years and $90.00 \%$ were 40 years or above. This showed an upper middle age for goat farmers, although a high proportion was still within an active age range. Age was significant at the 1\% level and was positively related to output. This revealed a strongly upper middle-age demographic for goat farmers, although a high proportion was still within an active age range. This matched a previous study that found the active age of goat farmers as a positive factor for better decision-making and sustainability in the animal husbandry (Ajala et al., 2008). The study clarified goat production in the study area was a mature adult business and suggested that middle age farmers were engaged in goat production. This is associated with the number of experiences gathered by the farmers over the years.

Education played a pivotal role in this demographic of the farmers as most of the goat farmers were educated and could read and write efficiently as no formal education statistics were recorded in the study. The positive farmers' education level was significant at $1 \%$ level and was positively related to output. These findings indicated that the higher the level of education of the farmers the higher the output and productivity of goat production. Thus, the findings conform to our priori expectation as high literacy levels allow the farmers to gain knowledge, skills, accept changes, keep proper records and adapt to use new innovations and technologies for increased productivity(Collett and Gale, 2009; Lwoga et al., 2011; Young et al., 2015).

The household size of goat farmers was relatively moderate and within a normal local average household size of 4-7 persons. The household size of goat farmers was also significant at $1 \%$ level and was directly related to output and productivity. This indicated that the higher the household size, the higher the output and productivity of goat produced. Increased household size increased family labour which minimizes the cost of hired labour for goat production. Previous studies also suggested that goat farmers can engage their family members in some farm work to increase output, reduce cost of hired labour, and reduce the cost of production (Ajala et al., 2008).

Farming experience (years) of goat farmers was also an important factor to determine output. The coefficient of farming experience was significant at $1 \%$ level and was positively related to output. This implied that the more the experienced farmers rear goats and get involved in production, the more they acquired information which affects their output positively. Both experience and educational levels can impact on the methods of production, management ability, record keeping and access to market opportunities (Kosgey et al., 2006).

Most goat farmers were small scale farmers with an additional livelihood and were found to be on a moderate level income. The farm size was mainly 1-5 goats or 21-25 goats in stock and constitutes small scale farming. The result of farm size was statistically significant at $1 \%$ level but was negatively related to output. This showed that the higher the farm size the lower the output and productivity. However, it does not conform to apriori expectation as the goat farmers were small scale farmers. The farmers combined their main occupation with goat farming to supplement their household livelihood. Goat farming therefore contributes significantly to the livelihood of smallholders and the present study agrees with previous claims that smallholders rear goat for supplementary income, food and manure (Chamboko et al., 2014).

Cobb-Douglas production functions output showed that farm size, family labour and capital inputs impact significantly on the output of goat production. This implied that an increase in the output of goat production in the area depends significantly on farm size, family labour and capital. The result also showed that any $1 \%$ increase in the farm size and family labour will increase production 
output by $82 \%$ and $40.8 \%$, respectively. Capital conversely had a negative relationship with the output indicating that any 5\% increase in capital will decrease production output by $22.00 \%$ as this implied that goat production is not capital intensive in the study area. Again, an increase in family labour will reduce the cost of production which will then lead to an increase in net production output. The result of allocative efficiency indicated that a unit increase in the farm size, and family labour and a decrease in capital will cause an increase in the production output of goat by $84 \%, 1 \%$ and $72.5 \%$ in the study area chosen and thus were all over utilised. The common over-utilization of family labour input could be attributed to the high cost of non-family labour emergent from labour scarcity in the area. Our findings align with the study on labour input in fish farming in Imo, and Anambra States in Southern Nigeria (Obasi, 2004; Ugwumba, 2010).

The result also showed that the common type of goat production and management in the area was extensive system. Goat farmers in rural areas usually leave their goats unsupervised for grazing and roam around which can lead to goats grazing in people's farm, thereby destroying their crops. Previous studies showed that such practice can lead to reduced output through goat thefts, accidents, exposure to disease and various other risks (Githiori et al., 2006; Bishop and Morris, 2007). The result corroborates with some studies that small ruminants were mostly managed under extensive systems of production in Southwest Nigeria (Adesehinwa and Okunlola, 2000; Ajala et al., 2008) and Northern Nigeria (Ajala and Gefu, 2003). They noted that variations in the use of systems of production depends on the management priorities and cost. Direct measures on the use of extensive system of production in the study suggests low rates of productivity for the mode. Thus, the predominant use of alternative systems of production where animals are not exposed to high production costs will be preferred. In low production costs, supplementary feeds are not provided, and the animals scavenge and feed on farm/kitchen wastes. This system results in poor performance and productivity of goats and cannot scale up to larger nutrient requirements and market size through scavenging alone (Peacock, 2005; De Vries, 2008). This may be seen to a critical constraint faced by the goat farmers in the study area.

The constraints faced by the goat farmers in the study area include; poor veterinary services, inadequate skilled labour, poor housing, poor road network, market problems, high diseases incidence, high costs of drugs, and high costs of feed used in goat production. The result of the study further showed that poor veterinary services remain a major constraint associated with the losses in livestock production, reduced production efficiency and decreases in overall productivity (Gwaze et al., 2009; Fikru and Gebeyew, 2015).

\section{CONCLUSION}

The study analysed production and management of goat rearing in rural area of Ezinihitte Mbaise, Imo State. The study showed that factor like age, farm size, educational level, household size and farming experience were significant socioeconomic factors affecting goat production and management systems in the area. Interestingly, the study found that farm size, family labour and capital inputs impact significantly on the output of goat production and management in the study area. However, the study observed that increased inputs do not necessarily lead to increased profit in traditional or indigenous goat farming system. The animal husbandry in the area relied on free grazing/extensive methods comprising of poor-quality browsing feedstuffs that resulted to low output and productivity. The result found poor veterinary services, inadequate skilled labour, poor housing facilities, poor road network, market problems, high diseases and pest incidence, high cost of drugs and feeds as major constraints faced by the goat farmers in the study area.

\section{RECOMMENDATIONS}

Based on the findings, the study recommends that strong efforts should be put in place to educate goat farmers and retains experienced and aged farmers in the business. This is to ensure increase in output and utilisation of opportunities for increase in productivity and profit returns. Effort should also be made to encourage the young ones into the goat production for sustainability in future. Communal awareness by researchers, animal scientists, extension agents and government bodies on improved management practices of goats farming should be encouraged to reduce counter-intuitive in over-utilization of resources. Favourable government policies towards creation of stable goat market in the study area would clearly drive the increase output and encourage more participation in the production and management.

\section{REFERENCES}

Adam H., Atengdem P.B. and Al-Hassan S. (2010). Innovations adoption levels of small ruminant farmers in Tolon-Kumbungu district of Ghana: The role of farmer socio-economic characteristics. Ghana J. Dev. Stud., 7 (2), 30-46

Adams F. and Ohene-Yankyera K. (2014). Determinants of factors that influence small ruminant livestock production decisions in Northern Ghana: Application of Discrete Regression model. J. Biol. Agric. Health, 27, 310-321

Adesehinwa A. and Okunlola J. (2000). Socio-economic constraints to ruminant production in Ondo and Ekiti States. Moor J. Agric. Res., 1 (1), 93-97

Ajala M. and Gefu J. (2003). Socio-economic factors influencing small ruminants management practices in Kaduna state. Moor J. Agric. Res., 4 (2), 274-280

Ajala M., Lamidi O. and Otaru S. (2008). Peri-urban small ruminant production in Northern Guinea Savanna, Nigeria. Asian J. Anim. Vet. Adv., 3 (3), 138-146 
Ajibefun I.A. and Daramola A.G. (2003). Efficiency of microenterprises in the Nigerian economy. African Economic Research Consortium, Nairobi, Kenya, 1 - 50

Ali A., Tegegne A. and Banerjee A. (2002). Slaughter component yield characteristics of some indigenous goat types in Ethiopia. Ethiopian J. Anim. Prod, 2 (1), $87-95$

Bishop S. and Morris C. (2007). Genetics of disease resistance in sheep and goats. Small Ruminant Res., 70 (1), 48-59

Chamboko T., Ziteya T., Muzanhindo N. and HanyaniMlambo B. (2014). Socio-economic factors influencing goat milk production in the smallholder areas of Zimbabwe: A case study of Bulilima East District. Livestock Res. Rural Dev., 26 (7)

Collett K. and Gale C. (2009). Training for rural development: Agricultural and enterprise skills for women smallholders. City \& Guilds Centre for Skills Development, 24-30

De Vries J. (2008). Goats for the poor: Some keys to successful promotion of goat production among the poor. Small Ruminant Res., 77 (2-3), 221-224

Dossa L., Rischkowsky B., Birner R. and Wollny C. (2008). Socio-economic determinants of keeping goats and sheep by rural people in southern Benin. Agric. Human Values, 25 (4), 581-591

Duku S., Price L., van der Zijpp A. and Tobi H. (2011). Influence of male or female headship on the keeping and care of small ruminants: the case of the transitional zone of Ghana. Livestock Res. Rural Dev., 23 (1), 1-10

FAO (2005). Livestock Sector Brief: Nigeria. Food and Agriculture Organization (FAO) of the United Nation. Livestock Information, Sector Analysis and Policy Branch. AGAL, pp 1-18

FAOSTAT (2008). FAO statistical databases-agriculture. http://faostat. fao.org/site/567/default.aspx

Fikru S. and Gebeyew K. (2015). Sheep and goat production systems in Degehabur Zone, Eastern Ethiopia: challenge and opportunities. Adv. Dairy Res., 3 (2), 1-9

Githiori J., Athanasiadou S. and Thamsborg S.M. (2006). Use of plants in novel approaches for control of gastrointestinal helminths in livestock with emphasis on small ruminants. Vet. Parasitol., 139 (4), 308-320

Godfray H., Beddington R., Crute R., et al. (2010). Food security: the challenge of feeding 9 billion people. Science, 327 (5967), 812-818

Gwaze F.R., Chimonyo M. and Dzama K. (2009). Communal goat production in Southern Africa: a review. Trop. Anim. Health Prod., 41 (7), 1157-1168

Jaitner J., Sowe J., Secka-Njie E. and Dempfle L. (2001). Ownership pattern and management practices of small ruminants in the Gambia-implications for a breeding programme. Small Ruminant Res., 40 (2), 101-108
Karbo N., Bruce J. and Otchere E. (1999). The role of livestock in sustaining soil fertility in northern Ghana. ILEIA Newsletter, $15 \quad$ (1/2), 49-50. http://edepot.wur.n1/79858

Kosgey I., Baker R., Udo H. and Van Arendonk J. (2006). Successes and failures of small ruminant breeding programmes in the tropics: a review. Small Ruminant Res., 61 (1), 13-28

Lebbie S. (2004). Goats under household conditions. Small Ruminant Res., 51 (2), 131-136

Livestock Report (2006). Food \& Agriculture Organization of the United Nations. Animal Production Health Division. Food \& Agriculture Organsiation

Lwoga E., Ngulube P. and Stilwell C. (2011). Challenges of managing indigenous knowledge with other knowledge systems for agricultural growth in subSaharan Africa. Libri, 61 (3), 226-238. http://210.1515/libr.2011.1019

Obasi P. (2004). Economics of fish farming in Imo State, Nigeria. J. Agric., For. Soc. Sci., 2 (1), 40-46

Oguoma N. (2003). Financing small rumminant operations along gender lines in Imo State, Nigeria. $J$. Agric. Soc. Res. (JASR), 3 (1), 13-28

Okali D., Okpara E. and Olawoye J. (2001). The case of Aba and its region, Southeastern Nigeria. Rural-Urban Interactions and Livelihood Strategies Series: Working Paper 4 International Institute of Environment and Development, London

Oyeranti O. and Olayiwola K. (2005). Policies and programmes for poverty reduction in rural Nigeria. African Economic Research Consortium (AERC), 1-51

Peacock C. (2005). Goats - A pathway out of poverty. Small Ruminant Res., 60 (1-2), 179-186

Poole N., Chitundu M. and Msoni R. (2013). Commercialisation: a meta-approach for agricultural development among smallholder farmers in Africa? Food Policy, 41, 155-165

Simela L. and Merkel R. (2008). The contribution of chevon from Africa to global meat production. Meat Sci., 80 (1), 101-109

Thornton P.K. (2010). Livestock production: recent trends, future prospects. Philosophical Transactions of the Royal Society of London B: Biol. Sci., 365 (1554), 2853-2867

Ugwumba C. (2010). Resource use efficiency and determinants of catfish production output in Anambra State, Nigeria. Multidisci. J. Res. Dev., 15 (1), 143-150

Wint W. and Robinson T. (2007). Gridded livestock of the world. FAO, Roma (Italia)

Young J., Evans S., Kocinski, Bush R. and Windsor P. (2015). Improving smallholder farmer biosecurity in the Mekong region through change management. Transboundary and Emerging Diseases, 62 (5), 491504. http://410.1111/tbed.12181 